\title{
UPRAVLJANJE TELEVIZIJSKOM PROGRAMSKOM ŠEMOM: ZNAČAJ SERIJSKOG PROGRAMA
}

\section{TELEVISION SCHEME MANAGEMENT: THE IMPORTANCE OF THE SERIAL PROGRAM}

\author{
Pavle Šeguljev, Iva Šiđanin, Fakultet tehničkih nauka, Novi Sad
}

\begin{abstract}
Oblast - INŽENJERSKI MENADŽMENT
Kratak sadržaj - U radu se razmatra značaj serijskog programa u televizijskoj programskoj šemi, kao i odnos auditorijuma prema ovoj programskoj vrsti. Istraživanje auditorijuma ukazuje na veliku gledanost serijskg programa ali i na minimalne promene gledalačkih navika u poslednjih šest meseci.
\end{abstract}

Ključne reči: Televizijski program, Medijski auditorijum, Televizijske serije.

Abstract - The paper discusses the importance of a serial program in a television program scheme, as well as the relationship of the audience to this type of program. Audience research indicates a large viewership of the serial program, but also a minimal changes in viewing habits in the last six months.

Keywords: TV program, Media Audience, Television Series.

\section{UVOD}

Serijski program predstavlja okosnicu ne samo programske šeme televizijskih emitera, nego i poslovanja globalnih kompanija koje pružaju striming usluge (Netflix, Amazon, $H B O G O$ ). Uspeh koji televizijske serije ostvaruju meri se brojem njihovih gledalaca i/ili pretplatnika, odnosno prihodima koje ostvaruju njihovi emiteri. Da bi se stvorila uspešna televizijska serija, neophodno je ispuniti mnogobrojne faktore. Eskenazi [1] naglašava da su to najčešće komercijalno-finansijski, produkcioni, tehnički, kao i kreativni i kulturološki faktori.

Istovremeno, dok zvanični podaci o zastupljenosti programskih vrsta na televizijama s nacionalnom frekvencijom u Srbiji ukazuju na godišnji pad učešća serijskog programa u ukupnoj programskoj ponudi [2], svedoci smo razvoja tržišta proizvodnje ovog medijskog sadržaja i hiperprodukcije dramskih serija. Prva serija domaće produkcije, koju je u svoju ponudu uvrstio jedan od najvećih svetskih striming servisa Amazon Prime, i na taj način omogućio njenu globalnu gledanost, jeste serija pod nazivom Senke nad Balkanom [3]. Serija Besa je, takođe, doživela veliki međunarodni uspeh, pozicionirajući se kao prva srpska serija prema čijem scenariju se snima adaptacija za inostrano tržište [4].

\section{NAPOMENA:}

Ovaj rad proistekao je iz master rada čiji mentor je bila dr Iva Šiđanin, docent.
Uspeh ovih serija, snimljenih u poslednje tri godine, korespondira s povećanjem sadržajnog i produkcionog kvaliteta, visokom profesionalnošću svih aktera, kao i većim ulaganjima u medijsku industriju u Srbiji.

Televizijske serije dostižu globalnu popularnost. U tom smislu Eskenazijev [1] tvrdi da je TV serija jedini žanr igranog programa koji može da zadovolji konformističku potrebu gledaoca za rutinom. Uprkos činjenici da se preko brojnih striming platformi može pristupati različitim medijskim sadržajima, kao i da više nismo vezani za tradicionalan način televizijske forme emitovanja, serije se, nasuprot nekim drugim formatima, ističu poštovanjem istih narativnih formula i predstavljaju deo receptivnog rituala. Đurković [5] skreće pažnju na to da serije nude obrazovne, zabavne, manipulativne, komercijalne i/ili ideološke mogućnosti.

Istorijska fikcija i fantazija su danas jedan od najpopularnijih književnih žanrova [6], te ne iznenađuje globalna popularnost serije Igra prestola. Ovo umetničko ostvarenje, percipirano je kao omiljena serija među učesnicima istraživanja sprovedenog za potrebe ovog rada, ali i kao serija strane produkcije koju je $u$ jednom dahu propratio (bindžovao) najveći broj participanata. Takođe, Igra prestola bila je najpretraživanija serija u Srbiji na Guglu tokom 2019. godine, ispred serija domaće produkcije Žigosani u reketu, Ubice mog oca 3 i Senke nad Balkanom 2 [7].

$\mathrm{S}$ obzirom na značajan porast proizvodnje serijskog programa zanimljivo je bilo istražiti odnos medijskog auditorijuma prema ovoj vrsti programa. Cilj je bio da se utvrde eventualne promene u gledalačkim navikama televizijske publike u pogledu praćenja serijskog programa, zatim njene sociodemografske karakteristike, učestalost praćenja ovog programa, kao i opšti odnos auditorijuma prema medijskom (meta)žanru kakvi su igrani serijali.

\section{ZASTUPLJENOST SERIJSKOG PROGRAMA NA TELEVIZIJAMA S NACIONALNOM POKRIVENOŠĆU U SRBIJI U PERIODU OD 2015. DO 2020. GODINE}

Serijski program predstavlja jednu najgledanijih i najzastupljenijih programskih vrsta na televizijama $\mathrm{s}$ nacionalnom pokrivenošću. Tako je, na primer, $u$ toku 2019. godine ova vrsta programa bila druga najzastupljenija na televizijama RTS 1 (18,11\%), Prva $(21,87 \%)$ i O2 $(14,95 \%)$, dok je na komercijalnim televizijama Pink $(8,58 \%)$ i Hepi $(3,49 \%)$, bila treća, odnosno četvrta, odmah posle rijaliti i informativnog programa [2]. 
Prosečno učešće serijskog programa u ukupnom emisionom vremenu na televizijama s nacionalnom pokrivenošču u periodu od 2015. do 2020. godine (Tabela 1), iznosilo je $13,92 \%$. Međutim, analiza godišnjeg proseka zastupljenosti serijskog programa u ukupnoj programskoj ponudi emitera ukazuje na pad programske zastupljenosti ovog žanra. Od $15,27 \%$, koliko je iznosio godišnji prosek za 2015 . godinu, zastupljenost serijskog programa je pala na $12,44 \%$ što je predstavljalo prosek za 2019. godinu.

Na RTS 1 (20,14\%) emitovano je skoro četiri puta više serijskog programa nego na RTS $2(5,6 \%)$. Na kanalima Radio-televizije Srbije najviše serijskog programa je emitovano 2018. godine - 14,89\%.

Tabela 1. Zastupljenost serijskog na televizijama s nacionalnom frekvencijom [2].

\begin{tabular}{|c|c|c|c|c|c|c|}
\hline \multirow{2}{*}{$\begin{array}{c}\text { Naziv } \\
\text { emitera (\%) }\end{array}$} & \multicolumn{5}{|c|}{ Serijski program / učešće (\%) } & \multirow{2}{*}{$\begin{array}{c}\text { Prosečno } \\
\text { učešće (\%) }\end{array}$} \\
\hline & $\begin{array}{l}2015 . \\
\text { godina }\end{array}$ & $\begin{array}{l}2016 . \\
\text { godina }\end{array}$ & $\begin{array}{l}2017 . \\
\text { godina }\end{array}$ & $\begin{array}{l}2018 . \\
\text { godina }\end{array}$ & $\begin{array}{l}2019 . \\
\text { godina }\end{array}$ & \\
\hline RTS 1 & 15,02 & 21,61 & 23,05 & 22,92 & 18,11 & 20,14 \\
\hline RTS 2 & 3,77 & 3,38 & 6,25 & 6,85 & 7,75 & 5,6 \\
\hline TV Pink & 16,65 & 12,54 & 10,46 & 9,11 & 8,58 & 11,47 \\
\hline TV Prva & 35,54 & 27,51 & 25,88 & 20,16 & 21,87 & 26,19 \\
\hline TV B92/O2 & 18,21 & 16,83 & 21,07 & 14,92 & 14,85 & 17,18 \\
\hline TV Happy & 2,24 & 4,25 & 4,33 & 0,38 & 3,49 & 2,94 \\
\hline $\begin{array}{c}\text { Godišnji } \\
\text { prosek (\%) }\end{array}$ & 15,27 & 14,35 & 15,17 & 12,39 & 12,44 & 13,92 \\
\hline
\end{tabular}

Najveće prosečno učešće serijskog programa emitovanog na komercijalnim emiterima ostvarila je Prva srpska televizija $(26,19 \%$, što je za $6 \%$ više nego na $R T S 1)$, a zatim televizije B92/O2 (17,18\%) i Pink (11,47\%). Televizija Happy je, generalno, imala najmanju zastupljenost ovog žanra u posmatranom vremenskom intervalu, s prosečnim učešćem od $2,94 \%$.

Serijski program obuhvata sadržaje domaće i strane produkcije, s približno ustaljenim terminima emitovanja tokom godine. U udarnim terminima (prime time) su, najčešće, emitovane serije domaće produkcije, nezavisno od toga da li je reč o premijernom ili repriznom prikazivanju.

\section{ISTRAŽIVAČKI DEO RADA}

\subsection{Predmet, cilj i uzorak istraživanja}

Predmet istraživanja su bili stavovi i mišljenja učesnika istraživanja o serijskom programu na televiziji. Cilj istraživanja je bio u tome da se utvrdi sledeće: učestalost i način praćenja serijskog programa; najomiljenije serije domaće i strane produkcije; emocionalno-kognitivni intenzitet praćenja serijskog programa (bindžovanje); i eventualne promene gledalačkih navika u poslednjih šest meseci.

Uzorak istraživanja činilo je 98 ispitanika, od čega je bilo $68,4 \%$ osoba ženskog i $31,6 \%$ muškog pola. Posmatrajući starosno doba učesnika istraživanja, najzastupljenija su bila lica starosti od 18 do 29 godina $(45,9 \%)$, zatim od 30 do 44 godine $(25,5 \%)$, kao i onih između 45 i 60 godina $(21,4 \%)$. Lica starija od 60 godina činila su 7,1\% od ukupnog uzorka. Među učesnicima istraživanja najviše je bilo visokoobrazovanih, odnosno onih koji su završili četvorogodišnje $(39,8 \%)$ i master studije $(27,6 \%)$. Sa završenom srednjom školom bilo je 18,4\% ispitanika, a onih koji su imali diplomu više škole (drugi ili treći stepen) $-11,2 \%$. Diplomu doktora nauka imalo je samo $2 \%$ ispitanika. Uzorak je koncipiran tako da obuhvati stanovnike dva najveća grada u Srbiji - Beograd (26\%) i Novi Sad $(44,9 \%)$, kao i njihova prigradska naselja $(29,1 \%)$. Zaposlenih ispitanika je bilo $64,3 \%$, a status studenta je imalo 20,4\% učesnika ankete. Nezaposlena lica su činila $11,2 \%$, a penzioneri $4,1 \%$ uzorka istraživanja.

\subsection{Metod i instrument istraživanja}

Istraživanje je bilo kvantitativnog tipa, a prikupljanje podataka se vršilo na osnovu anketnog metoda. Kao instrument istraživanja korišćen je elektronski upitnik, kreiran putem opcije Google Forms.

Onlajn upitnik je sadržao ukupno 25 pitanja grupisanih u pet celina (socio-demografska obeležja; praćenost serijskog programa; premijerno i reprizno emitovanje; vrsta produkcije; bindžovanje; promene gledalačkih navika u poslednjih šest meseci), sa ponuđenim modalitetima odgovora, pri čemu su dva pitanja sadržala Likertovu skalu, dva numeričke skale procene, dok su tri pitanja bila otvorenog tipa. Upitnik je distribuiran putem imejl adresa i Vibera, metodom grudve snega [9], dok su podsaci obrađeni kroz statistički program direktno na Google Forms-u. Istraživanje je sprovedeno u periodu od 17. do 26. avgusta 2020. godine.

\subsection{Rezultati istraživanja}

\subsubsection{Praćenost serijskog programa}

Generalno posmatrano, istraživanje je pokazalo da je serijski program veoma gledan. Naime, 82,7\% učesnika istraživanja je izjavilo da prati ovaj medijski sadržaj. Skoro polovina ispitanika (49\%) je ovu programsku vrstu gledala povremeno, $18,4 \%$ retko a $15,3 \%$ njih redovno. Ipak, bilo je i onih koji nisu pratili sadržaje koji spadaju u kategoriju serijskog programa, a takvih je bilo $17,3 \%$.

Serijski program, na osnovu procene onih koji su ga pratili, najčešće se gledao dva do tri puta nedeljno $(48,1 \%)$, odnosno jednom nedeljno (19,8\%). Ređe od jednom nedeljno ovu programsku vrstu pratilo je $13,6 \%$ ispitanika, a pet puta nedeljno njih 12,3\%. Samo $6,2 \%$ učesnika istraživanja gledalo je serijski program svakog dana.

Vremenski interval u kom su se u najčešće gledale serije je večernji - od dvadeset jednog sata do ponoći $(77,8 \%)$. Značajno manji procenat učesnika istraživanja pratio je serijale u terminima između 18,00 i 21,00 časova $(14,8 \%)$, odnosno od ponoći do 6,00 sati ujutru $(3,7 \%)$. U popodnevno vreme, od 14,00 do 18,00 sati serijski program je pratilo samo $2,5 \%$ ispitanika. U prepodnevnom intervalu, od 10,00 do 14,00 sati, ove sadržaje je pratilo $1,2 \%$ učesnika istraživanja.

Prema rezultatima istraživanja, televizijski prijemnik je bio za 59,3\% učesnika istraživanja uređaj putem kog se najčešće gledala ova vrsta programa. Ipak, trećina učesnika istraživanja (37\%) procenila je da to najčešće čini putem svog laptop/PC računara. Pametni telefon $(2,5 \%)$ i tablet $(1,2 \%)$ nisu deklarisani kao uređaji adekvatni za gledanje serijskog programa. Tome verovatno doprinosi i manja dimenzija ekrana.

U okviru svoje programske ponude svi eiteri, nezavisno od toga da li se radi o televizijama $\mathrm{s}$ nacionalnom frekvencijom ili kablovskim kanalima, imaju raznovrstan serijski program. Učesnici istraživanja su naveli da 
serijale najćešće gledaju na TV Prva $(40,7 \%)$, a zatim na RTS 1 (33,3\%), TV Pink (9,9\%), B92 (8,6\%) i RTS 2 $(3,7 \%)$. Nijedan učesnik istraživanja nije pratio serije na Happy $T V$, dok skoro jedna trećina učesnika istraživanja (32,1\%) uopšte nije pratila ovae sadržaje na televizijama s nacionalnom pokrivenošću. Fox Life $(34,6 \%)$ i Nova $S$ (24,7\%) su dve kablovske televizije na kojima je najveći broj učesnika istraživanja gledao serijski program, a zatim sledi $H B O-19,8 \%$.

Kriminalističke (58\%) i humorističke (54,3\%) serije spadaju u dva omiljena žanra serijskog programa. Učesnici istraživanja su navodili kao omiljeni žanr i dokumentarne serije $(28,4 \%)$, zatim dramske, s ljubavnim zapletom $(22,2 \%)$, te naučno-fantastične $(16 \%)$ i istorijske $(14,8 \%)$ serije (Grafikon 1).

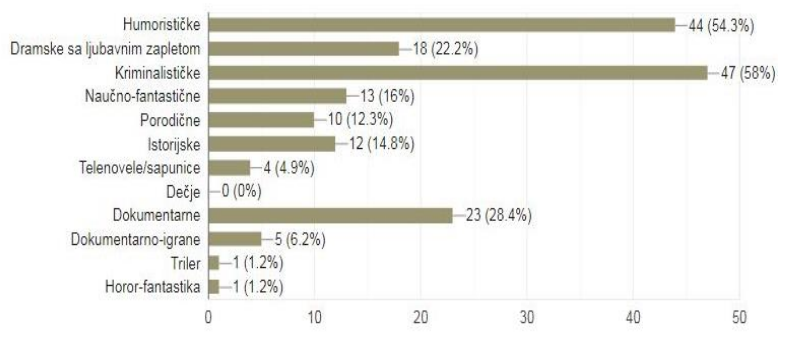

\section{Grafikon 1. Omiljeni žanr serijskog programa}

Senke nad Balkanom je serija koja je bila procenjena kao najomiljenija za $32,1 \%$ učesnika istraživanja. Zatim slede serije: Besa (27,2\%), Ubice moga oca (25,9\%), Južni vetar (23,5\%), i Andrija i Anđelka (22,2\%). Serija Vratiće se rode procenjena je kao najbolja domaća serija svih vremena prema iskazima $19,8 \%$ anketiranih lica, zatim serije Otvorena vrata $(14,8 \%)$, Bolji život $(9,9 \%)$ i Grlom u jagode $(8,6 \%)$.

Presudni faktor u odabiru serije, prema mišljenju najvećeg broja ispitanika su: radnja, tj. priča $(74,1 \%)$, žanr $(55,6 \%)$, izbor glumaca i kvalitet glume $(44,4 \%)$. Manjem broju ispitanika bili su važni: jezik na kom je serija snimljena $(11,1 \%)$, kanal na kom se serija emituje i izbor reditelja $2,5 \%$.

\subsubsection{Odnos prema premijernom i repriznom emitovanju serijskog programa}

S obzirom na to da se na televizijama emituje i veliki procenat repriznog serijskog programa, bilo je zanimljivo utvrditi odnos učesnika istraživanja prema praćenju ove programske vrste kako u premijernom, tako i u repriznom terminu emitovanja. U tom kontekstu, procenjen je odnos prema gledanju premijernih epizoda omiljene serije. Više od polovine učesnika istraživanja $(54,32 \%)$ se u potpunosti složio s procenom da ,serije gledaju preko interneta, u terminu kada za to imaju vremena". Nešto manje od polovine učesnika istraživanja $(45,68 \%)$ se delimično složilo s procenom da „najviše vole da gledaju serije u premijernom terminu emitovanja", kao i s procenom da „ukoliko nisu u mogućnsti da gledaju seriju u premijerom terminu emitovanja, to obavezno učine u roku od 24 časa putem opcije odložnog gledanja" (37,04\%).

Takođe, procenjen je i odnos prema praćenju repriznih epizoda omiljene serije. Učesnici istraživanja se, $u$ najvećem procentu, nisu u potpunosti složili ni sa jednom od navedenih procena. Međutim, u najvećem broju su se delimično složili sa nekoliko njih: „uvek pogledam reprizu serije strane produkcije koju volim, kada je vidim na TV-u" $(48,15)$, ,generalno ne volim da gledam reprize serija” (43,21\%), ,uvek odgledam reprizu domaće serije koju volim, kada je vidim na TV-u” $(41,98 \%)$, i ,,volim da gledam reprize starih domaćih serija koje se emituju na RTS1” (40,74\%). S procenom „volim da gledm reprize domaćih serija preko interneta" uopšte se nije složilo $65,43 \%$ ispitanika, a s procenom ,volim da gledam serije strane produkcije preko interneta", njih $38,27 \%$.

\subsubsection{Odnos prema vrsti produkcije serijskog programa}

$\mathrm{Na}$ osnovu analize zastupljenosti programskih vrsta na televizijama s nacionalnom frekvencijom, primetna je zastupljenost velikog broja serija strane produkcije, među kojima dominiraju one turske proizvodnje. Zanimalo nas je da li se gledaoci serijskog programa radije opredejuju za praćenje domaćih ili stranih serija, na kom jeziku su serije koje vole da gledaju, kao i to koje su im omiljene serije, u zavisnosti od vrste produkcije. Učesnici istraživanja podjednako vole da gledaju i domaće i strane serije $(39,5 \%)$, međutim, ipak je više onih koji se opredeljuju za serije strane produkcije $(38,3 \%)$, u odnosu na serije domaće produkcije $(22,2 \%)$. Samim tim, ne iznenađuje ni podatak da je engleski jezik (77,8\%) procenjen kao jezik na kom su serije koje se najčešće prate. Srpski jezik je drugi najpoželjniji (60,5\%). Ispitanici vole da gledaju serije i na španskom (12,3\%), turskom, ruskom - 3,7\% ili nekom drugom jeziku. Ukoliko govorimo o vrsti produkcije serijskog programa koji se prati, među učesnicima istraživanja bilo je dominantno povremeno gledanje serijskog programa engleske $(56,79 \%)$ i američke $(44,44 \%)$ produkcije (Grafikon 2). Najveći broj učesnika istraživanja je retko gledao latio-američke serije $(48,15 \%)$, a gotovo nikad turske $(48,15 \%)$ i ruske $(38,27 \%)$.

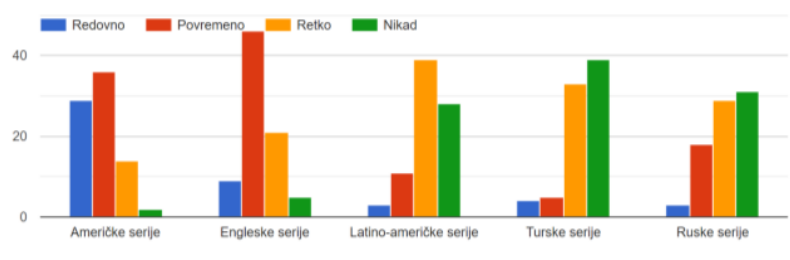

Grafikon 2. Gledanost serija strane produkcije

Veliki broj visokobudžetnih domaćih serija snimljen je u poslednje tri godine, te nas je zanimao odnos učesnika istraživanja prema ovim sadržajima. Za procenu stavova je korišćena Likertova skala. Ni za jednu tvrdnju nije bio izražen maksimalan broj učesnika istraživanja koji su se sa njom u potpunosti slagali, ili se nisu slagali. Najveći procenat ispitanika se složio sa sledećim tvrdnjama: ,produkcioni kvalitet serija je na izuzetno visokom nivou" (37,04), ,sadržajni kvalitet serija je na izuzetno visokom nivou" $(29,63 \%)$, ,u seriji ima mnogo više scena nasilja" (38,27\%), i „serije deluju skuplje” (32,10\%). Takođe, najveći broj učesnika istraživanja je bio neodlučan u vezi sa procenama: ,velika pažnja se posvećuje estetici” (46,91\%), „serije su edukativne” (44,44\%), „koristi se veliki broj vizuelnih efekata" $(40,74 \%)$, „u serijama ima mnogo više eksplicitnih scena" $(35,8 \%)$, ,pojavljuju se raznovrsniji žanrovi” $(34,57 \%)$ i ,angažovani su najbolji glumci” $(28,27 \%)$. S tvrdnjom da 
su strane serije „mnogo kvalitetnije od domaćih” nije se složilo $32,10 \%$ ispitanika.

\subsubsection{Bindžovanje serijskog programa}

U novije vreme praćenje serijskog programa je sve popularnije usled pojave televizijskih i internet paketa poput Netflix, Amazon i sl., pa se sve češće upotrebljava termin bindžovanje, odnosno praćenje serija u ,jednom dahu". Ovo je u direktnoj vezi sa mogućnostima koje se pružaju u okviru paketa sa inovativnim uslugama, što gledaoci rado koriste za praćenje više epizoda u toku dana, ili čak celih serijala. Nešto manje od polovine učesnika istraživanja $(44,4 \%)$ bindžovalo je više od jedne serije u svom životu, a samo jednu seriju njih $21 \%$. Ipak, trećina ispitanika nikada nije bindžovala serijski sadržaj $(34,6 \%)$. Serija koja se ubedljivo najviše bindžovala je Game of thrones. Serije strane produkcije, koje su se takođe gledale „u jednom dahu” su Grey's Anatomy i La casa de Papel, kao i serija domaće produkcije Senke nad Balkanom.

\subsubsection{Praćenje serijskog programa u prvih šest meseci tekuće godine}

Zbog epidemološke situacije izazvane virusom COVID19, najveći broj ljudi je poslednjih šest meseci proveo u svojim domovima, obavljajući radnej aktivnosti od svoje kuće. Shodno tome, imali su i više slobodnog vremena nego inače. Rezultati istraživanja su pokazali da se najveći broj učesnika istraživanja $(28,4 \%)$ složio s procenom da su u poslednjih šest meseci počeli da gledaju serije koje do tada nisu gledali. Takođe, najveći broj učesnika istraživanja se nije slagao sa sledećim tvrdnjama: „pogledao/la sam sve epizode omiljenih serija” (33,33\%), ,gledanje serija je postalo deo redovne porodične zabave" $(32,1 \%)$, „češće sam gledao/la serije preko interneta nego do tada" $(30,80 \%)$, „češće sam gledao/la serijski program nego do tada” $(29,63 \%)$, „,̌ešće sam gledao/la serije preko TV-a nego do tada" $(28,4 \%)$. Deo ispitanika $(32,1 \%)$ se nije slagao, odnosno se slagao sa procenom da su ,slobodno vreme provodili gledajući serijski program". Najveći broj ispitanika $(48,15 \%)$ se nije pretplatilo na Netflix, odnosno na neku drugu platformu radi praćenja serijskog programa $(59,26 \%)$. Procenat od $30,86 \%$ ispitanika je izjavio da nije počeo da bindžuje serijski programa, tj. da ga prati $u$,jednom dahu”.

\section{ZAKLJUČAK}

Televizijske serije su jedan od najzastupljenijih, nauticajnijih i najpopularnijih oblika popularne kulture [5], i kao takve aktivno oblikuju svakodnevni život, stavove i vrednosti gledalaca [10].

$\mathrm{S}$ obzirom na to da je u Srbiji u poslednje tri godine snimljen veliki broj visokobudžetnih serija koje po tematici, produkciji i kvalitetu mogu da pariraju najboljim stranim serijama, ne iznenađuju stavovi učesnika istraživanja da su produkcioni i sadržajni kvaliteti na visokom nivou i da serije deluju ,skuplje”. Međutim, ispitanici su bili mišljenja da savremene serije obiluju mnogo većim brojem nasilnih scena, nego što je to bio slučaj sa serijalima snimanim u prethodnim decenijama. Ipak, kriminalističke, uz humorističke serije, privlače najveći broj gledalaca.
Medijski stručnjaci u poslednje vreme kritikuju domaću serijsku produkciju, navodeći da nedostaju serije humorističkog karaktera, te da serijali ne ispunjavaju svoju osnovnu kulturološku i zabavnu funkciju.

U tom smislu poznati scenarista Siniša Pavić, navodi da se u aktulenim serijalima pojavljuju kalpi, šabloni, manirizmi, kao i da je medijski marketing i agresivno propagiranje novih serijala postalo važnije od samog scenarija, režije i glume [11]. Slične, kao i sve glasnije kritike, koje dolaze iz kompetentnih izvora, otvaraju prostor za dalja istraživanja u oblasti specifičnog i složenog medijskog (meta)žanra, kakav je serijski program.

\section{LITERATURA}

[1] Ž. P. Eskenazi, „Televizijske serije”. Beograd, Clio, 2013.

[2] http://www.rem.rs/sr-lat/izvestaji-i-analize/izvestaji-ianalize-o-nadzoru-emitera/izveshtaji\#gsc.tab=0 (pristupljeno $u$ avgustu 2020.)

[3] https://www.nedeljnik.rs/ekskluzivno-amazonotkupio-senke-nad-balkanom-prva-domaca-serija-nanekoj-od-velikih-platformi-zvace-se-black-sun/ (pristupljeno u septembru 2020.)

[4] https://www.danas.rs/kultura/adaptacija-domaceserije-besa-za-arapsko-trziste/ (pristupljeno u septembru 2020.)

[5] M. Đurković, „Prva petoletka: domaće televizijske serije i transformacija Sistema vrednosti u tranziciji”, Sociološki pregled, Vol. 39 (4), pp. 357-381, 2005.

[6] B. A. Pavlac, "Game of Thrones versus History: Written in Blood", Hoboken, Wiley Blackwell, 2017.

[7] https://itmagazin.info/fudbal-i-domace-serijenajpretrazivaniji-pojmovi-na-google-u-srbiji/ (pristupljeno u avgustu 2020.)

[9] P. Oliver, "Snowball Sampling". In Jupp, V. (ed.), The SAGE Dictionary of Social Research Methods.

Thousand Oaks, Sage Publications, 2006.

[10] N. Simeunović Bajić, M. Vujović, D. Pavlović, D. "The 1990s on the RTS Screens: Analysis of the Domestic Television Series and the Audience Attitudes", Issues in Ethnology and Anthropology. Vol. 15(2), pp. 469-487, 2020.

[11] https://kosutnjakfilm.rs/sinisa-pavic-pola-veka-pisenaj-tv-serije/(pristupljeno u septembru 2020.)

\section{Kratka biografija:}

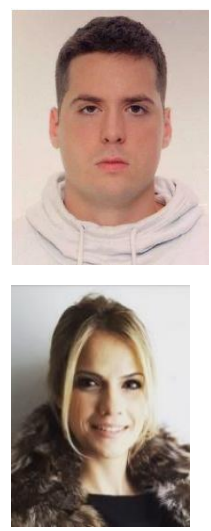

Pavle Šeguljev rođen je u Novom Sadu 1995. godine. Završio Fakultet za poslovne studije u Beogradu. Upisao je Master akademske studije na Fakultetu tehničkih nauka 2019. godine iz oblasti Industrijsko inženjerstvo i menadžment.

Iva Šiđanin rođena je u Novom Sadu 1984. godine. Doktorirala je na Fakultetu tehničkih nauka. U zvanju je docenta i angažovana je na predmetima iz oblasti Menadžmenta medija. 